\title{
KEY SPECIFICITIES OF SOCIAL FABRIC UNDER NEW-CAPITALISM ${ }^{1}$
}

\author{
ZSUZSA FERGE $E^{2}$
}

\begin{abstract}
The paper describes manifestations of inequality and poverty evolving under new-capitalism in Hungary. The new aspects of inequality include unlimited force-fields and unbridled competition between them, new divisions in inequality, and the absence of both ceiling and floor. The new features of poverty include massive and lasting joblessness leading to the socialization of children in an atmosphere of hopelessness, extreme social exclusion turning entire micro-regions into poor and Gypsy ghettos, demeaning forms of workfare and the like.

About half of Hungary's residents have lost out in the regime change, meaning that they are worse off now than before. Roughly half the losers are poor and about half a million of them (the entire population of the country is ten million) were poor both before and after the change. The new inequality and poverty is a challenge to all Hungarians, particularly to politicians and the poor themselves. Responses are often distorted because the sudden and extreme occurrence of poverty has spawned a vehement rejection of the poor, often combined with rapidly spreading racism.
\end{abstract}

KEYWORDs: inequality, new-capitalism, poverty, racism

The factors that fundamentally define the fabric of social relations - including the structure of resources - have been turned head-over-heels when compared to conditions under state socialism. "The dominant role once played by political power in structuring relations has given way to the power of capital in a market-run society. It has also split society into the categories of 'own-

1 This is a somewhat reworked chapter from the book entitled, Társadalmi áramlatok és egyéni szerepek (Social flows and individual roles) Napvilág Kiadó, 2010. The manuscript was submitted in March, before April's parliamentary elections, so only some references are made to the new political situation.

2 Zsuzsa Ferge is professor emerita, head of research at the Office of Programmes against Child Poverty of the Hungarian Academy of Sciences e-mail address: fergesp@t-online.hu 
ers' and 'everyone else'. Nevertheless, there are a wide variety of vertical and horizontal links connecting the two halves of the playing field. The change in structural relations means that private ownership has become more or less dominant while political authority is no longer a decisive factor. The political game has become just one factor in the relationships which shape the social structure. The types of connection a person has to the labor market have become almost as important as ownership of capital as factors reshaping society and determining differences in individual opportunity. The two factors together determine the way a person can access the resources necessary for subsistence, the extent to which they may be accessed, and the entitlement under which the person may access them" (Ferge 2006). The resulting social fabric has several additional specificities when compared to state socialism.

I would like to focus on a single one of these specifics - the nature and impacts of inequality. I am starting to hope that reviving the idea of spotlighting inequality is growing into more than just a personal obsession. The demand to reduce inequality in schools has already become an international movement that has left a political imprint even on Hungary. In Hungarian public education, Equal Opportunity plans and the Integrated Pedagogical System were designed to meet this goal. These are mutually supportive tools which, if applied on both school and settlement level, give the school (or community) a chance to apply for various state subsidies based on the proportion of disadvantaged ("HH") or multiply disadvantaged ("HHH") children living and attending school there ${ }^{3}$. On an international level it is increasingly considered a public responsibility to reduce the social inequalities of decisive significance to life expectancy and quality of life (e.g. Marmot Review 2010). International research shows that inequalities do more than affect specific factors of living. Instead, they take on a life of their own, shaping the quality of a given society by preserving and passing on existing hierarchies from one generation to the next. This influence is independent of the economic level of a given country, or of how poor the poor are, or how affluent the well-to-do may be. Social epidemiologist Richard Wilkinson has drawn the conclusion based on decades of research that "...people in more unequal societies trust each other less, they are less likely to be involved in community life, and rates of violence are higher. All suggest that inequality damages the quality of social relations" (Wilkinson 2005, 2006) ${ }^{4}$.

The Stiglitz-Sen-Fitoussi Report (2009), which caused such a stir, also un-

3 The labels $(\mathrm{HH}, \mathrm{HHH})$ used for positive discrimination may easily become stigmas, a problem requiring further research.

4 http://socialbaby.blogspot.com/2006/01/richard-wilkinson-impact-of-inequality.html 
derlined the problem from the angle of economic and social sustainability. While the title of the report suggested issues of methodology and measurement, the three prominent economists (two of whom are Nobel laureates) pointed out that an outlook which narrowed down development to economic growth overlooked the most important aspects of human existence along with the whole of quality of life. Poverty plays a defining role in determining quality of life, but inequality has an even greater impact. Therefore, for example, Recommendation 7 of the Report read as follows: "Quality-of-life indicators in all the dimensions covered should assess inequalities in a comprehensive way".

\section{SPECIFICITIES OF NEW INEQUALITIES}

The specifics detailed below describe features of new-capitalism in Hungary as compared to the former system. Inequalities are growing in a global context, too. I did not study - at this point - whether the specifics here described differ from those of other countries.

\section{The possibility of an unlimited number of fields of force}

An important new twist to social relations is that there are no dictates coming from above or from the outside to regulate the set-up of the possible fields of force. There are no limits on the new economic, service, or similar entities, or on the political parties, newspapers or civic organizations that can be established. New methods of resolution - the fact that one may resign from an institution or may criticize an institution in any style - do have the power to mitigate certain conflicts. For instance, if there are conflicts within a political party that prove irreconcilable, there is nothing to prevent a split and a new party being formed. If there are methodological or other differences of opinion within a service organization such as a school, people can quit and even set up a new school. The rise in the number of force fields also generates new tensions and triggers dynamic possibilities. This may have two consequences as far as social hierarchies are concerned. In one instance, the organizations themselves may strive for exclusivity. Their goal is to concentrate people of similar social positions, promoting the formation of hierarchies and weakening ties between groups. But organization proliferation can also reduce competition for the top slots because the more organizations there are, the more 'head honchos' there can be. It is easy to get used to this kind of pluralism. 
In Hungary for instance, 3,200 mayors enjoy powerful positions of authority, rendering competition between the force fields even stiffer. For this reason the rise in the number of fields - a product and an advantage of democracy - also creates new costs. The costs of democracy - the lengthy process of building consensus instead of a single dictatorial decision - are usually high. They also require a long time to pay for themselves and it takes even longer before we learn that they are actually much more sustainable than are dictates. The payoff from the unlimited increase in the number of force fields is shakier. In all probability the increase in force fields and corresponding proliferation of "top slots" that goes along with it will heighten inequalities in distribution given the limited nature of resources. Those people who snare the top slots - heads of new institutions and the like - will usually do their best to obtain an income befitting their rank, which leaves even less money for the lower echelons. This may even appear to be acceptable and legitimate because society is gradually getting used to a growing level of inequality as a quasi new norm.

\section{Unlimited competition}

Not only are an unlimited number of new force fields coming into existence, there is nothing to limit competition between them once they do. Unfettered competition is obviously going to claim victims on an ongoing basis. Depending on our choice of values, we can see this as Schumpeterian "creative destruction" and an engine of growth, or as a social hazard. Although my anticompetition views are rather well-known (at least in Hungary; Ferge, 2009), I do recognize that global competition exists, which means that Hungary cannot ignore or negate it. The usual prescription offered for improving the country's international standing is to improve competitiveness. So, it would be nice to clarify what that actually means and what "improvement" depends on. Perhaps on getting individuals and businesses to be "competitive", meaning to compete with each other and drive each other out of business, as many people seem to think? Or maybe on how individuals and businesses manage to keep an eye on the country's common goals while making good in the business world? Accepting common goals obviously requires compromise and designing the compromises means having to cooperate. Quite a number of countries have demonstrated that cooperation within their borders boosts efficiency and profitability. There is good reason to assume that the international competitiveness of the whole of a country and the competitiveness of the individuals or the smaller units of the said country - such as businesses, local governments, ministries or units within ministries - are not in fact re- 
ally connected. In fact, cutthroat competition between individuals or smaller groups can end up being an obstacle to a country's international competitiveness while a measure of solidarity and cooperation will promote it. The economic downturn led to the surfacing of another problem - the fact that international competition is not necessarily in the interests of a country. Most likely, every single member of the European Union would have profited from authorizing the EU to manage the crisis for all of them. Sovereign solutions which differed from country to country have become sources of many new conflicts. Despite this, increasingly powerful interests are fighting for what they call the ideal of individual freedom, meaning that they want to eliminate all moral, legal, and political controls and regulations controlling competitive institutions.

\section{Growing inequalities may lead to deeper splits}

When the overall amount of resources increases, inequality may increase or decrease, and so can poverty. Even rising inequality does not necessarily mean that the poor are getting poorer. More specifically, for a long time we lived with the economic fable that if the economy grew, growth would eventually trickle down to the poor, alleviating poverty, if not necessarily reducing inequality. That fable has fallen by the wayside. It can be easily understood that if a large part of the profit (with or without financial bubbles) is limited to the global money market, none of that is going to trickle down anywhere. And if resources are declining, we can be pretty sure that the stronger groups will be better able to defend their shares than weaker ones. So, if the stronger groups are able to absorb surpluses even when resources are becoming scarce, the weaker ones are sure to lose out. The result is that social distances will grow and new social splits will come about.

The following is just a single example of what it boils down to when overall improvement and growing inequality lead to new splits. Infant mortality in Hungary was quite high for a long time, and it is now starting to drop. But people in better social and regional positions can take far better advantage of the conditions leading to the decrease. So the situation of people on the poor end of the scale keeps going downhill while the ones who are better prepared can profit from the new opportunities. A regional breakdown can illustrate the inequalities: there was a radical decline in infant mortality in Western Transdanubia (Western Hungary) between 2000 and 2007, and the rate now more or less corresponds to the EU average. But in the poorest region, Northern Hungary, the infant mortality rate has grown significantly (Figure 1). 
Figure 1 Infant mortality (Ratio of infants dying before their first birthday per 1,000 live births)

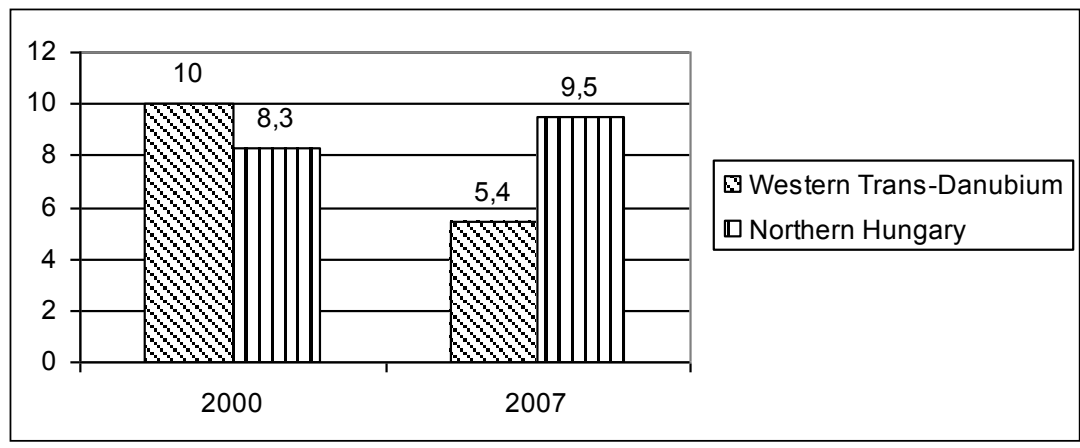

Source: http://www.ksh.hu/rss/indi/2/indi2_8_1.html

\section{There is no ceiling on inequality}

When competition is unlimited, so are the stakes. This is one reason behind the growth in inequalities in both income and assets. Although it is hard to monitor inequalities in income statistically, the rise in the luxury housing market and in luxury shops is rather conspicuous. Of course truly cutthroat competition may lead to the limiting of competition in the long run. In Hungary, the country's two best-known traditional giant meat processors, Pick and Herz, now have a single owner. In other words, the multi-player market, which might really be a progressive force, is dying. We do not expect to see any regulations whatsoever that set ceilings. For the moment, ceilings only come about when forced into existence by competition between or among force fields (the government may impose ceilings, for instance, on salaries but as the new regulations under preparation in Hungary show, they are limited to public-sector managers).

We are seeing the effects of the lack of a ceiling in other fields than income, too. In democracies, giving children equal opportunity to education for at least the first 12 to 16 years of their lives is a fundamental principle. However, if not all schools are equally good, the upper strata will try to get their children into the best of the schools. They use up a large portion of public (central and local government) resources to do this. If that fails, then they use private monies. This happened in Hungary long before the market appeared on the scene. Research done by our group in the early 1970s demonstrated that the differentiation of public (government-financed) schools by social classes, or 
more specifically the expropriation of the better schools by the upper and middle classes, existed even then. Yet, the regulations in place at the time, which restricted enrolment at a given school to children living in the school district, combined with the government's educational monopoly were powerful restrictive forces. Freedom of school choice, introduced in 1985, followed by the freedom to establish schools has significantly widened the gap. International surveys of school performance (PISA), which have been conducted since 2000, show that Hungary is one of the countries with the highest level of social discrimination between schools. The between-school variance of children's achievement levels is among the highest of the OECD countries and the within-school variance is among the lowest. This discrimination is both social and ethnic. The reduction or elimination of ethnic segregation (probably linked to EU pressure) has become a central goal, both of the government and of groups fighting for ethnic rights. Since about 2002, the government has been making serious efforts to reduce or eliminate ethnic segregation. While this effort may so far have included non-ethnic poor children, to date non-ethnic discrimination at the expense of "only" the poor has not managed to attract the attention either of the government or of researchers. Income and ethnic segregation currently determine to a large extent the unequal educational performances of Hungarian schools.

\section{There is no floor on inequality either}

The threat of joblessness and poverty first reared its head some 25 years ago, and by 1990 or so the picture of what was to come became shockingly clear. Nevertheless, the country and the political classes did very little to prepare to manage the trouble. The Employment Act of 1991 did offer temporary benefits to a sizable portion of the jobless. However, the relatively generous benefits and extensive entitlements of those early years have since been cut significantly. Sustenance for the poor was never guaranteed. Nevertheless, there has been fluctuation. The Social Act, originally adopted in 1993, introduced in the mid-nineties an income-substitution support that was not limited in time to cover the (frequent) occasions when unemployment benefits of an insurancetype expired. The government which came after terminated it in 1998, but the following government never restored it, so that this support disappeared. The level of eligibility for aid has fluctuated over the past 20 years with the on-andoff introduction of various conditionalities, culminating in 2008 in the "Road to Work program" (more on this later). The discretionary power of local authorities is varied. Sometimes they choose freely who they deem worthy of 
helping, even if the law does not give them that authority. The smaller a settlement, the greater the discretionary power of the mayor in deciding who gets how much and in what form (cash or kind). They do not have to worry about people protesting either. The Social Act does not assure an individual right of appeal, the people on the receiving end have no organized power, and there is no professional or legal oversight of local government operations. In 2006, public awareness about increasing poverty was growing. The dire poverty resulting from the low level of assistance was somewhat alleviated when the uniform amount of social assistance (offered both to long-term unemployed and so-called unemployable people) was supplemented so that it took family size into consideration. Although basic assistance adjusted to family size is the rule rather than the exception in EU member states, the Hungarian government gradually repealed this arrangement from 2009 on (in connection with the "Road to Work program"). Throughout this time, the need to set a minimum income level was not acknowledged either by the Social Act and its amendments or by any other disposition. Instead, rapidly changing and increasingly intricate legislation triggered the evolvement of a highly bureaucratic and often arbitrary assistance bureaucracy (Szalai, J. 2007). With increasing government austerity, the chances of setting such a floor are getting slimmer.

An oft-repeated demand is for some kind of social housing minimum, at least for families with children, to prevent this group - if only this group - from becoming homeless. The Parliamentary Commissioners for Civil Rights turned to the Constitutional Court, asking that the concept of 'social minimum' be interpreted to include the right to housing. The Constitutional Court rejected the proposal. Its reasoning was as follows: "Under paragraph (1) of Article 70/E of the Constitution, the right to social security includes the provision that the state must guarantee a minimum subsistence level through an ensemble of social benefits. Specifically defined rights - such as the "right to housing" - cannot be derived as a constitutional right from this minimum subsistence guarantee. Therefore, in such concrete matters, the obligation of the state and consequently its responsibility cannot be determined. Under paragraph (2) of Article 70/E of the Constitution the state is mandated to establish, sustain and operate a set of social insurance and social welfare institutions to realize the right of citizens to subsistence benefits. When establishing the system of social provisions ensuring minimum subsistence, the basic constitutional requirement is to protect human life and dignity. Consequently the state shall provide the basic conditions for human life, and in cases of homelessness it shall arrange for emergency accommodation to avert situations that directly threaten human life".

Other failed proposals included attempts to prevent utilities from being disconnected, at least in households with children. At the same time, however, 
debt service facilities, a crisis management fund and recent rules on subsidizing the price of district heat and gas have helped some families that have found themselves in debt, and have prevented others from ending up in debt. Nevertheless, none of this has been able to help people who are deep in debt or are very poor. Meanwhile, chances for poor people to improve on substandard housing situations have deteriorated. Opportunities to access socially-based housing subsidies were terminated in July 2009. Local governments lack the funds to build rental housing. Consequently, poor families obviously have no chance of upgrading their current homes and young families starting out in life are forced to share already overcrowded homes with their elders or live in substandard dwellings never meant for human habitation. In short, as of 2009, there is no floor on how deep into deprivation people can sink.

\section{NEW POVERTY - WHAT'S NEW ABOUT IT?}

The issue of poverty is perhaps the point where the new regime comes out worst when compared to state socialism. It is common knowledge that the flows that intensified poverty were already manifest in the 1980s, but shifted to acceleration mode after 1989.

Over one million jobs were lost in the early years following 1990. A large part of the new unemployed were absorbed by the pension system (causing hardship later). Hardest hit were the uneducated, the Gypsies and rural residents who could never return to the labor market. The unemployment rate rose to 10.1 percent by the autumn of 2009 and to 12.8 percent by the spring of 2010 . Meanwhile only 54 percent of the population was economically active, one of the three lowest rates in Europe. As labor law eroded and the number of jobs plummeted, existential uncertainty shot up. Among more immediate and well-known consequences (such as deterioration in health) this will have major negative repercussions in the future. Of particular concern is the socialization of children. In 2007 one-seventh of all children lived in households where there was no economically active person; and in many of them this has been the case for two or three generations. In 2007 this was the second highest proportion in Europe. Given the global crisis the situation must have deteriorated in quite a few countries, but in Hungary the downturn has been dramatic: in 2009, fully 21 percent of all children under 18, or one child in five was living in a family without a single economically active person. "Growing up hopeless" is a new experience.

The cost of home maintenance has increased quite disproportionately compared to income growth. The widening gap has led to massive indebtedness, 
evictions and homelessness - all new phenomena. In the spring of 2009, fully 750,000 families (not all of them are poor) were behind on mortgage payments, and 260,000 families had unpaid utility bills. The electricity had been switched off in 4,000 homes, and the number of families losing their homes and undergoing eviction climbed from a few hundred a year to well over 1,000. After the crisis hit evictions multiplied in 2010 (no statistics currently available).

Many people fled from the cities because of their inability to pay housing costs, and the better off cities or parts of cities did everything in their power to rid themselves of their poor and their Gypsy residents. The consequence is a new type of social exclusion, the "Gypsy ghettoization" of many microregions. More recently, there has been an influx of poor urbanites, including families with a larger number of children, to isolated farming communities. We have also witnessed a process more typical of Latin America, namely the emergence of favelas: shantytowns are evolving along the outskirts of larger cities, on abandoned weekend-home plots, or on the grounds of closed down factories and mines. Many of these ghettos and shantytowns have no internal leadership structures. Residents have no anchors and no prospects of improvement. These are hitherto unknown processes in Hungary.

- One of the obvious consequences of these phenomena is an increase in income inequality and poverty. The scale of poverty in Hungary qualifies as average for Europe, with about 12-13 percent of the population considered poor under a uniform European standard. Child poverty, however, is worse than the European average (around 25 percent in 2009). After 1990 there was a steep rise in income inequality and the proportion of poor people. Around 2007 it appeared that the rise in income inequality was slowing down. However, starting in 2008 the situation again began to deteriorate, partly because of the economic downturn and partly because of an indifferent (or malevolent) policy towards the poor. The real wages of those retaining their jobs fluctuated with the crisis. In the first two years of the crisis they decreased, and since 2009 employee wages have shown minimal growth. Pensioners suffered some losses (e.g. because of the new methods of indexing to prices) but they are still relatively protected from poverty. The unemployed and those receiving social benefits got a worse deal. The real value of social benefits, (family allowance included), social assistance, and unemployment aid dropped, partly because there has been no nominal increase in the amount distributed since 2008 and partly because the price index for the very poor rose much more steeply than the nationwide average. The crisis has accelerated the process of disintegration, and increased inequality, particularly among families with children. In 2009, already close to 30 per cent of all children under 18 lived in poverty, an unusually high rate. 
Table 1 Poverty rates in the whole population and among children (All persons in the given category $=100 \%$ )

\begin{tabular}{|l|c|c|c|}
\hline & Total population & $\begin{array}{c}\text { Persons living in house- } \\
\text { holds with children }\end{array}$ & Children under 18 \\
\hline 2001 & 13,5 & 19,9 & 22,8 \\
\hline 2003 & 13,8 & 19,4 & 22,4 \\
\hline 2005 & 13,2 & 18,1 & 20,0 \\
\hline 2007 & 12,7 & 19,0 & 20,1 \\
\hline 2009 & 16,5 & 27,3 & 29,6 \\
\hline
\end{tabular}

Source: 2001-2007: TÁRKI Household Monitor Surveys, (http://www.tarki.hu/hu/research/ hm/index.html). 2009: TÁRKI survey on families with children, 2009

The nature and role of the labor market has fully changed. Decades of full employment have been followed all over Europe by labor market difficulties. Some - mostly Scandinavian - countries try to maintain the formerly generous welfare arrangements combined with new active labor market policies. Others move more or less rapidly from "welfare" to "workfare'. The Hungarian "Road to Work program" introduced in 2008 seems to be a particularly harsh example of the workfare "culture". The legislation ties receiving the dole to work, namely community work. The government shifted responsibility for organizing and implementing the program to local governments but the money earmarked for this purpose includes very little for equipment, professional planning, or organization. So, as experience has shown, the poorer the settlement, the less community service it has available and the worse the jobs that it offers.

The new law (an amendment of the Social Act) separated people receiving assistance into two groups. Those assumed to be able to work (the large majority) went on a list of people "available to work". Hence the money they receive is called "Availability Support", (abbreviated as RÁT), corresponding to the minimum pension (an arbitrary and very low threshold) and not adjusted for family size. The prerequisite for receiving the RÁT is that the person must accept whatever public work is offered for at least 90 days a year (assuming that any is offered) for pay amounting to the mandatory minimum wage. If they refuse it, the sanction is suspension of the RÁT (and all other forms of support) for a longer or shorter period of time. The small minority deemed unable to work (people over 55, the chronically ill, or women with 3 or more children not in day-care) continue to get family-size-adjusted assistance. In the first year (2009) families continued to receive the earlier benefits; several RÁT-s if there were several unemployed members, or both RÁT 
and assistance. From January 2010 the new law has been fully implemented. From this point on, one family has a right to only one benefit - that is to only one RÁT, whatever the number of unemployed, or to one sum of assistance. If there is only one person on RÁT, the family supplement is lost. At the same time a more rigorous regulation of clandestine (unregistered) work was introduced combined with increased monitoring of compliance: if a person is caught working illegally, all aid is terminated.

The declared goal of the program is helping people to return to the labor market. This has proved a failure: only one per cent of those undertaking public work have returned to the open labor market. This is understandable. The work done locally, which makes no demands on people and requires no preparation, does not reinforce any skills that might help them on the open labor market. It is not the aid itself that acts as a counter-incentive to socially worthwhile work as economists usually see it, but isolation from real social opportunities. The other program goal was to pacify those who were set against rights to assistance without obligation to work. Yet the 'solution' has heightened animosity towards the poor. In some cases this was done by spreading the rumor that "all they do all day long is lean on their shovels", while in others it was "they get the same amount as I do", although I'm working a whole lot harder. In other words, if the poor people get anything at all, whether they work for it or not, society's opinion leaders qualify it as waste and throwing money out the window.

As a matter of fact, the Road to Work policy rests on contradicting a tenet of Roman law. According to this "no one can be required to do the impossible" (nemo potest ad impossibile obligari). However, the basis for the demand that the poor work is that "anyone who really wants work will find it". Since this is clearly a falsehood, the policies that rest on it are demanding the impossible and are therefore doomed to failure. Meanwhile, the policy significantly weakens social rights.

\section{ARE THE NEW POOR REALLY NEWLY POOR?}

Unfortunately, there is no set of data in Hungary that monitors the evolution of living conditions for individuals, families, and groups as a function of time $^{5}$. Even the retrospective surveys that compare past and present are few in number. There were two projects from which I can extract some information.

5 The Hungarian Household Panel survey that TÁRKI launched in 1992 was terminated after the sixth wave in 1998 because of a lack of funding.

CORVINUS JOURNAL OF SOCIOLOGY AND SOCIAL POLICY 2 (2010) 
The SOCO project conducted in 1995 (Ferge et al., 1996) tried to map out the regime change's winners and losers in several ways. Among other things, it compared how individuals placed themselves on a 5-point rating scale, where they marked their past and current social situations. They also marked their incomes for the given year and a time three years earlier along a ten-point scale. The 'winners' in the Figure are those who placed themselves higher on the social or income ladders in 1994 as compared to the 1980s, while the "losers" put themselves lower. The survey covered five countries. I will not go into detail here, but would mention only that Hungary has the fewest winners and most losers. Polish and Slovak data were similar to ours, while the Czechs and Germans qualified the changes as being more favorable than the other three countries. One interesting point is that people saw changes in their social situations as somewhat less advantageous than changes in their income situations (Figures $2 a$ and $2 b$ ).

Figure 2a Distribution of respondents by change in income in 1994, compared to 3 years earlier, \%*

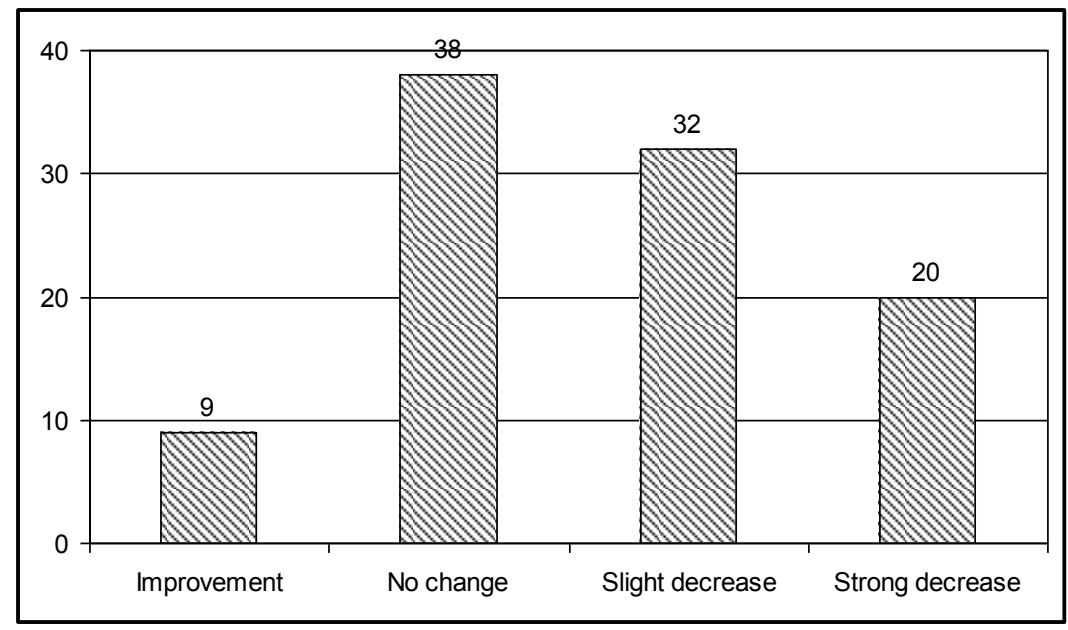

* The respondents placed themselves on a seven-grade scale representing the income hierarchy in the country (seven being the highest and one the lowest grade) for several periods. In this figure two placements were compared and regrouped. 
Figure $2 \boldsymbol{b}$ Distribution of respondents according to change in their perceived social position in 1994 as compared to the eighties, \%*

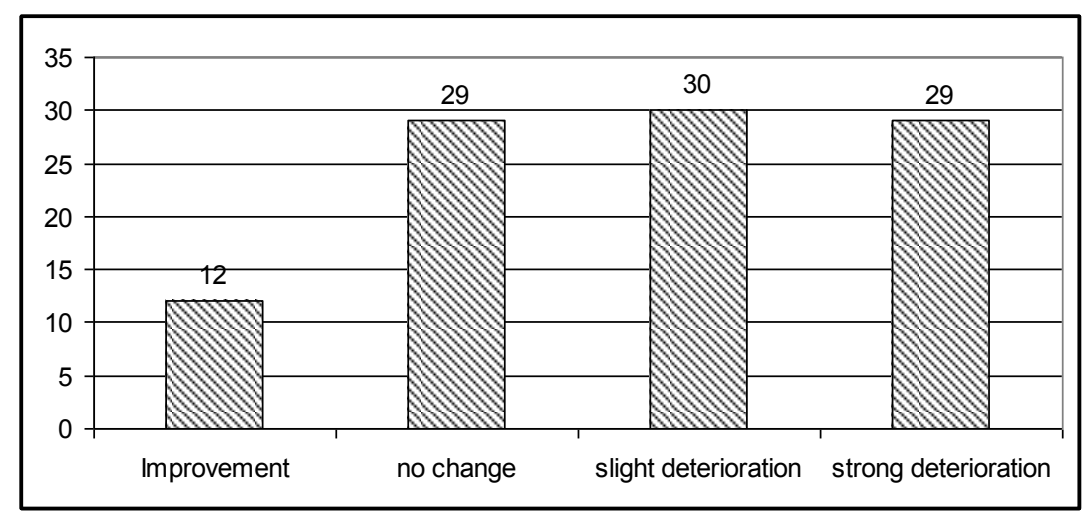

*The respondents placed themselves on a seven-grade scale representing the social status hierarchy in the country (seven being the highest and one the lowest grade) for several periods. Here the 1980s, and the present (1994) were compared and regrouped.

Source: SOCO database, Ferge et al., 1996

The perception of being a winner or a loser was related to several factors, including occupation, educational level, subjective poverty and the loss of a job. On an occupation scale, blue-collar workers had the strongest perceptions of loss. Both positive and negative assessments were closely related to educational levels (Table 2).

Table 2 Change of the perceived social position between the 80's and 1994 (the time of the interview) by educational level of the head of household

\begin{tabular}{|l|c|c|c|c|c|}
\hline & $\begin{array}{c}\text { Max. } \\
\text { primary }\end{array}$ & Vocational & Secondary & Higher & Total \\
\hline $\begin{array}{l}\text { Significant } \\
\text { deterioration }\end{array}$ & 34 & 31 & 23 & 20 & 29 \\
\hline $\begin{array}{l}\text { Slight } \\
\text { deterioration }\end{array}$ & 28 & 29 & 33 & 27 & 30 \\
\hline No change & 31 & 27 & 29 & 31 & 29 \\
\hline $\begin{array}{l}\text { Slight } \\
\text { improvement }\end{array}$ & 5 & 12 & 13 & 18 & 10 \\
\hline $\begin{array}{l}\text { Significant } \\
\text { improvement }\end{array}$ & 3 & 1 & 2 & 3 & 2 \\
\hline Total & 100 & 100 & 100 & 100 & 100 \\
\hline
\end{tabular}

Source: SOCO database, Ferge et al., 1996 
In the early 1990 s, nearly 60 percent of Hungarians qualified themselves as losers, five times more than the number of winners. Not all of the losers were poor, but there was a strong correlation. Nearly 40 percent of losers and 20 percent of winners were in the lower income third (tertile), meaning that nearly 70 percent of the lower income third said they were losers (Ferge et al, 1996). In other words, the regime change hurt the people who had also earlier a high risk of poverty, namely people with less education, and of course, the Roma, more than average

We do not have the data to continue the story in the same vein. There is, however, a TÁRKI research project that is something of a stopgap. In 2007, researchers sought out the people for whom they had collected data for the first Hungarian Household Panel project in 1992 (Kolosi-Tóth, 2008). The outcome was a collection of information on 3,000 people covering a 15-year time span. Nearly 60 percent of the people who were poor in 1992 (that is, people who assigned themselves in 1992 to the lowest 25 percent when it came to income and assets) were in much the same situation in 2007 and only 7 percent had managed to improve their lot to among the top 25 percent which is a lower ratio than that of the people who managed move upward with the regime change (12\%). Vice versa, 18 percent of the people in the middle group and 9 percent of the people initially in the upper quartile became poor. To look at the numbers from a different angle, 56 percent of the people who were poor in 2007 (amounting to 14 percent of the population) had been poor ever since 1992. The factors we are already aware of - job losses, low education level or lack of opportunity in the family, Gypsy ethnicity, and a rural residence - were dominant factors in preventing an advance (Figure 3).

It is very difficult to link the two surveys quoted above. I shall still try to estimate the proportion of winners and losers in the social and financial sense. The winners are not necessarily rich but they are in a stable financial situation and have a comparatively high social status. The losers are not necessarily poor but their objective situation in life - income, social stature, and level of security - has deteriorated compared to 20 years ago. I will not give the details of my calculations. The only reason I provide the results of my estimate at all is because it would be absurd to have no picture whatsoever of these two epochal decades. I also want these estimated figures to act as a challenge. It would be very useful if other researchers came up with estimates and if we were to debate the social rationale of preparing balance sheets of this sort.

Thus, according to my (clearly and admittedly uncertain) assessments:

- The proportion of losers, meaning people whose positions have deteriorated since 1990 and about half of whom are poor, is between 45 and 50 percent; 
- About 30 to 35 percent are in the same position as they were before (financially and socially), although even "no change" can cover major changes over the course of 20 years;

- The proportion of winners, people whose situation has improved and who are currently in a good or very good position is about 20 to 25 percent.

Figure 3 Changes in self-positioning on the income-asset ladder between 1992 and 2007

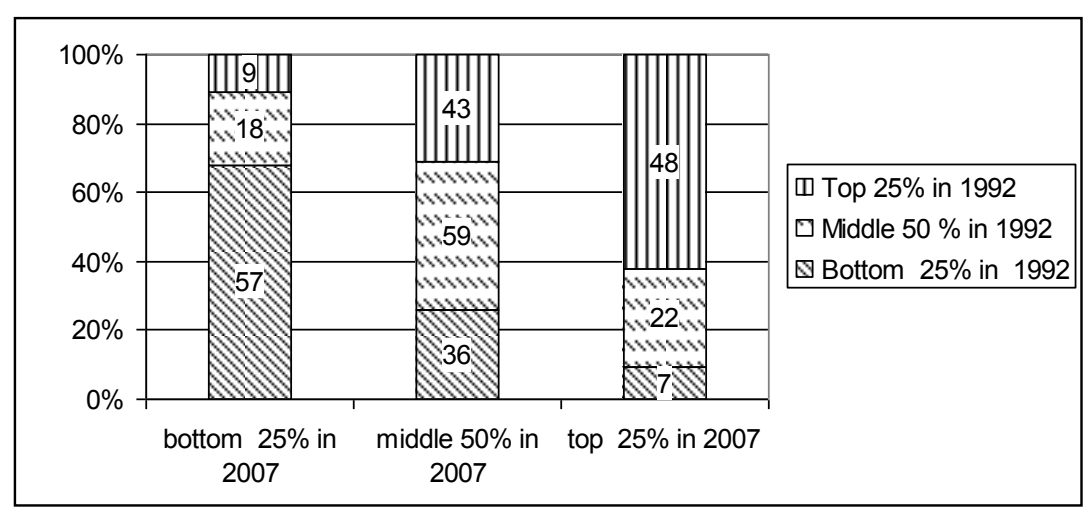

Source: Kolosi-Tóth 2008, Table 1.9.

The information available is too fragmented for me to even try to come up with a precise diagnosis of how many of today's poor have inherited their poverty over the past two or three generations, and how many have only been poor for the past 20 years. One part of the question involves who we define as poor. The inaccurate estimate given above and the outcomes of a number of my own past research projects (Ferge, 2005) encourage me to believe (and I would be delighted if it turned out that someone else had better data) that if we define the lowest 25 percent of incomes as 'poor' (excluding retirees) then perhaps one-third of them - equivalent to 7-8 percent of the (non-retired) population- come from multi-generational poverty. That amounts to 500,000600,000 people. The situation of the others deteriorated later on, and perhaps only temporarily. We simply do not know how lasting their poverty is. Based on earlier Hungarian data ${ }^{6}$, which monitored the same people for two to three years, and on international data, we can assume that a significant portion of

6 Shorter follow-up surveys were conducted earlier by the Central Statistical Office and TÁRKI. As required by the EU, the Statistical Office is returning to the panel-type method with the SILC data survey as of 2008. 
the people who are poor at a given moment in time are only poor for a few years, with the poverty triggered by some turning point in their lives such as a birth, a death, or a job loss. Meanwhile the inhabitants of the new poor and Gypsy ghettoes are likely to have joined the vicious circle of multigenerational poverty.

\section{RESPONSES TO THE CHALLENGES OF GROWING INEQUALITY AND POVERTY}

\section{How does society see inequality and poverty?}

One tragic outcome of the new social system is poverty and even less hope of reversing inherited destitution, while another is that with twenty years behind us, society has turned against the poor and the destitute. The process is known from world history. If there are only a few poor people, they will receive social sympathy and assistance, which does not cost too much. If some sort of social upset or crisis causes their numbers to grow, supporting them becomes more of a social burden. To put it bluntly, they cost more. That leads to a gradual decline in social sympathy and willingness to help. When the first homeless people came out in public in 1989, humorist and entertainer András Nagy Bando and local residents offered them tea and sympathy. Sympathy with people who lost their jobs was obvious. Since then things have gone downhill.

The real contradiction in this story is that while inequalities in many countries continue to grow (with or without government intervention) a significant portion of European society has always considered the inequalities to be too large and believed it a government task to reduce them (Figure 4).

In this area hardly anything has changed in the past twenty years. The East European bloc is taking a slightly stronger stance against inequalities than the Western one, but in both blocs anti-inequality feelings predominate and variations are significant. The majority of public opinion condemns too much inequality. Yet public opinion has never connected inequality with the rise in poverty. Political behavior appears to be pretty similarly unable to connect the two issues. Thus, people continue to reject inequality while aversion to poverty is growing and politics can tout an anti-poor edge.

The ratio of Gypsies is growing among the poor, the extremely poor and particularly among young people and families with children (since the Gypsies tend to have a 10-12-year shorter life expectancy than average, their ratio within the population as a whole has not shown a particularly significant rise 
in the last years). Gypsies, unless they are driven out of towns, tend to be more visible than non-Gypsies. Beggars and homeless people (for the most part non-Gypsies) are also more visible. The non-poor find it nearly impossible to process this. For a time they tolerated the beggars and the homeless, but after a while they found the spectacle disturbing. Psychologically, it became a symbol that this could happen to them, too, as well as an accusation - why have you let this happen? So local governments passed laws one after the other, banning beggars and homeless people from the more affluent parts of the towns, or from entering the towns altogether.

Figure 4 "To what extent should it be the government's responsibility to reduce income differences between the rich and the poor". (Ratio of answers" definitely should be" and "probably should be" as percentage of all respondents in the cell). 1996 and 2006

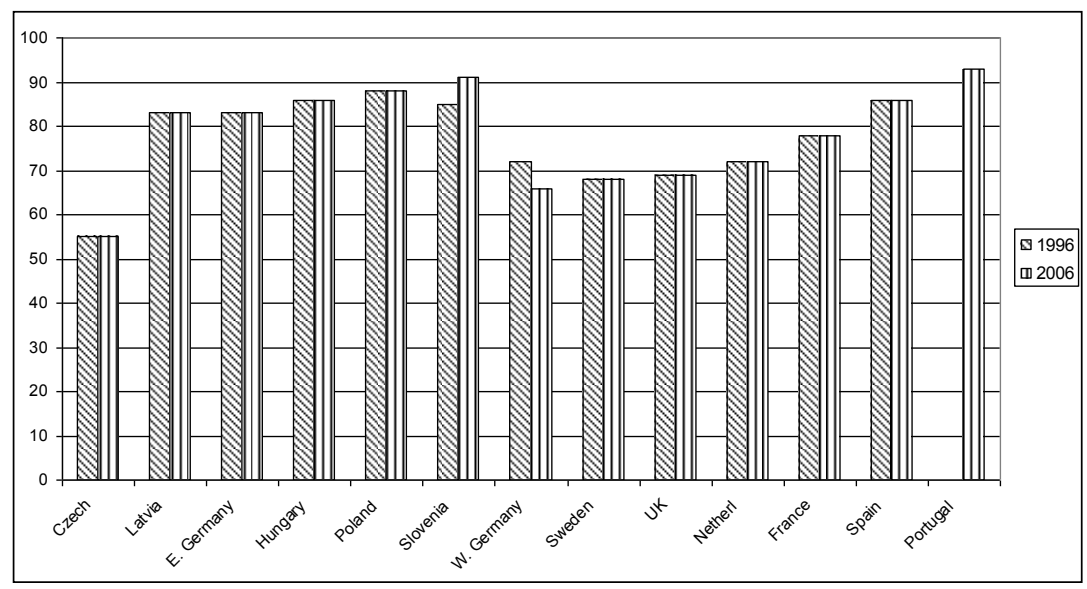

Source: ISSP 1996, 2006. (http://www.gesis.org/en/services/data/survey-data/issp/modulesstudy-overview/role-of-government/1996/ and same, 2006

\section{How does the world of politics manage poverty?}

Political - central and local government - responses to poverty can be good or bad. My main point is that policies that do not treat poverty as a structural issue, as a phenomenon related to inequality, that are narrowed down to poverty management, are bound to fail. Nevertheless, even a narrowed-down policy of poverty management can be better or worse. Despite some unquestionably good intentions within Hungarian politics, the overall poverty management 
policy has many negative features. Some of them are particularly disturbing. They include unpredictability, disregarding the facts, frequent ineffectiveness and populism. I will illustrate each of these using an example.

Unpredictability. Both rules and outcomes can be unpredictable. The legislative environment is far from stable. The Social Act (Act III., of 1993 on social welfare administration and social services and benefits) has been amended 58 times between the time it was adopted and March 2010, meaning nearly four amendments a year. This has triggered the same number of changes in local ordinances and in implementation decrees for 3,200 local governments. The situation is much the same for the Child Protection Act (Act XXXI. of 1997 on the protection of children and the custodial administration), which has been amended 41 times in 12 years, and the Family Support Act (Act LXXXIB of 1998) which had been amended 29 times in 10 years (Erdős, 2010). No one can keep up with this deluge of amendments, triggering a good number of unlawful consequences. Among other things, it is impossible to attach this vast number of amendments to every copy of the law in print, which means that legal actions are certain to be full of contradictions. The legislation itself gives rise to uncertainties. Each year the law governing the budget can amend the amount of cash benefits involved. For instance, each year a decision is taken on whether to peg benefits to other payments such as pensions or leave them floating, and whether to tax them or not. The law that establishes the budget can also alter the rules of eligibility for the various services and the financing conditions, annually should it wish to. This unpredictability not only hurts the quality of legal regulation and administration, but it is also a serious blow to families who have no way of knowing whether they can count on child-care assistance, paid child-care leave for working mothers, family allowances or anything else (since elections in April 2010, the new administration has been passing legislative amendments at breakneck speed, too).

Examples of disregarding the facts are the family allowance, the Road to Work program, and the helter-skelter and thoughtless way of shifting cash benefits to benefits in kind. Let me focus on the family allowance. We know for certain from all domestic and international descriptions and data that the universal benefit, meaning an across-the-board family allowance granted to every single child, is the most effective way of countering poverty. The cost of transferring this benefit to all families is low, the take-up rate is almost 100 per cent, a rate never approached by assistance schemes, and it can even be calibrated to family situation and/or the age of the child. Despite this, constant demands on the part of Hungarian liberals, and more recently of the new "Hungarian conservatives", are that family allowances be limited to lowincome families, that they be taxed, that tax cuts would be a better idea, or 
that they be linked to various conditions such as school attendance. The idea of abolishing the universal family allowance has been repeatedly proposed and rejected over the last two decades. In principle there was always one condition, regular school attendance: if a child was consistently missing from school, the parent would have been fined or even incarcerated. This happened very seldom, though - public administration knew that most of the families were unable to pay fines and incarceration seemed too extreme. Under a new law adopted in June 2010, the family allowance has been renamed. For children under six years of age it is now called an "educational benefit", while for children over six it has become a "school attendance allowance". If a child over 6 misses over 50 hours of classes and has no medical or other explanation, the school attendance allowance is suspended for 6 months. It depends on the local authority whether the family can get an equivalent amount in kind through the ministrations of the child protection agency, starting with the second month of the suspension. In their haste to introduce the sanction, the new government made no attempt to collect facts or to understand the mechanisms or causes of truancy. There is no evidence to tell us how widespread truancy actually is, only conjectures suggesting that the phenomenon occurs often among the over-14, and is most common in non-academic secondary schools (schools for learning trades). Therefore there are no studies about the possible impact of the new measure. There has been no attempt to determine either why children who were never liked by the school or who were never offered any help or encouragement, tend to play hooky, nor did the legislators consider that reducing the income of a family that is poor at the outset will in all likelihood enhance all norm-violating behaviors.

I will demonstrate ineffectiveness using one of the key objectives of the education system, desegregation, showing how it went awry. Since the early 2000 s a great deal of effort has gone into reducing the level of segregation. A variety of financial incentives were introduced in successive order (offering among other funds, normative support for integration) as were administrative prescriptions demanding integration. There was no monitoring of what happened to the financial incentives, and though the funds have been used, the effects were dubious. Schools and bodies maintaining the schools managed to find loopholes enabling them to satisfy requirements on paper while actually reinforcing segregation (for instance, schools were merged to produce improvement in the overall ratios of the school and the averages covered up continued segregation in the newly merged schools whose ethnic composition remained unchanged). Outstanding among the administrative measures was the altering of school-district boundaries. The new law introduced in January 2007 required children to attend their district school, eliminating the free 
school choice that had led to widespread segregation. The new law was not preceded by any measure of preparation and there was no dialogue with parents, teachers, or children. It should not surprise anyone that the law remained toothless. The children "moved" to addresses in the school zone of choice, or families actually moved, or in a worst case scenario they founded private schools. A recent analysis by Gábor Kertesi and Gábor Kézdi (2010) based on a complete set of longitudinal data, drew the painful conclusion that while between 1980 and 1990 there was no change in the segregation of Gypsy children in school, from 1990 onwards segregation grew significantly, year on year. If Julia Szalai is right and school segregation is doing an excellent job of performing a latent function - legitimizing the wall between deep poverty and the non-poor by making separation the rule rather than the exception and thus expanding the isolated childhood way of life into lifelong isolation - a halt to and reversal of current processes would require overall social change and not "targeted aid to the poor" (Szalai 2010).

By political populism, I mean that politics adjusts to what it thinks it hears as "the will of the people." Irresponsible promises of increasing distribution are just as populist as decrees that yield to prejudice or racism, because the politician or political party expects them to boost their popularity. Populist promises have been a part of the campaign strategy of just about every single political party before every election. Populism that yields to divisive views anti-poverty, anti-Gypsy, chauvinist - was originally limited to the right wing. However, in the past year or two every single political party has become populist in both senses and every one of them has its racists (who in many cases indignantly reject this qualifier).

\section{The popular "demand" for racism}

Racism is spreading. It is helped by prejudice that is reinforced by myths presented as facts (with strong media support). Myths generally have some root in history or experience and are then expanded to the point where they become mistaken for reality in general. The allegations that distort reality and shape general attitudes towards the poor might be true for a fraction of the group. Generalization of the myth makes it appear that the objectionable behavior is typical of every single poor person. This gives rise to the stereotypes: "these people" do not like, do not want, do not know how to work; "these people" spend taxpayer money on themselves, not their children; "these people" drive Mercedes-Benzes and wear gold chains when picking up their assistance - in other words, they are cheaters -; or "these people" have 
children just to get the family allowance. Some of these legends are worded to mean "Gypsy" so that, for instance, the expression, "Gypsy crime" has become widely accepted. This is how poverty is turned into a Gypsy matter, which leads to an even sharper rejection of any assistance. The most recent addendum to these legends, which has been voiced by socialist politicians, conservatives, and even a leading gynecologist, is: "these people/mothers" use medication or rubber mallets to deliberately disable their unborn children to get a higher level of family allowance. This myth differs from the others in a number of ways. First of all, it does not contain even a grain of truth. No one has been able to cite a single case where this has happened. Instead everyone who espouses this tale heard it from someone else who heard it from someone. And if someone should name a village, the responsible village elders and the involved parties alike are bewildered by the charges and helplessly protest. Reliable researchers argue that there is no way anyone can come up with a concrete case because a foetus cannot be injured to cause specific disabilities with the methods cited. The charges are particularly cruel because of the undercurrent of ritual slaughter. They hint at the deliberate damaging of one of the holiest of values, the unborn child, and as such the legend is particularly good at stirring up a firestorm. Acceptance of this legend exempts the political world from having to do anything to counter the conditions that really do lead to the birth of so many low birth-weight infants at the poor end of the spectrum or from doing anything to encourage more deliberate "family planning".

These myths legitimize the existing laws and the ones on the planning board that restrict the rights of the poor and completely deny them their dignity. New regulations and laws-to-be are reintroducing the requirement to perform senseless work, are limiting freedom of consumption and are interfering (considered the right of the taxpayers) in every corner of their private lives. One of the recent exploits of a mayor (and Member of Parliament) is the publication (in July 2010) on the internet of a list of names (complete with birth dates) of 'cheaters' whose criminal offence is that they did not pick up the free meal or the food parcel they applied for and hence "squandered taxpayers' money". This Wall of Shame has been warmly approved of by government. Another proposal made also by an MP in October 2009 aims at the introduction of a "social welfare card". All assistance money should be transferred to the card which would only be used to purchase basic necessities in designated shops. The goal is "to establish a fair, targeted, and transparent assistance system". The argument in favor of it was given thus: "When a system is supported and maintained by taxpayer money, an absolute requirement is that beneficiaries truly spend the government benefits to cover the needs of the family and 
the children. There is a real danger with the current cash payment system that a portion of social support may be spent on unhealthy luxury consumer goods (i.e. tobacco and alcohol), gaming machines or may wander into the hands of loan sharks, rather than going for food, clothing and home maintenance". These allegations, declaring everyone a suspect, and therefore subject to collective punishment, are, to put it mildly, mistaken. They also suggest a 'civilization gap'. Elizabeth Gaskell's genre novella, My Lady Ludlow was published in 1858. In it one of her characters visits the poor and "...she asked too many home questions (not to say impertinent) concerning their domestic economies (for even the very poor liked to spend their bit of money their own way), and would open cupboards to find hidden extravagances..." (Elizabeth Gaskell, 1995, p. 160). Every single research study in Hungary has found that in poor and non-poor families alike, in the vast majority of families well over 90 percent - "children come first." If they are hungry the reason is almost always a lack of money. The reason there is a lack of money is a lack of work, a low level of assistance, and usurial interest rates. Now, nobody borrows money at usury rates for sheer pleasure. They do it because there is something they absolutely must have money for - to pay an urgent bill, to pay interest on another loan, to buy medicine, or to buy bread. It makes one wonder how people will be protected from predatory lenders if they have even less cash at their disposal.

The fight against racism has been severally put back on the political agenda. Yet, public funding and political will have always remained insufficient, and the awareness of civil society has been weak. Anti-poor emotions have triggered a situation in which the political class believes that people are demanding populist measures. One factor feeding the populism is a growing anti-Gypsy mood, and increasingly barefaced racism. Hatred of the Gypsies has been growing as have provocative actions that threaten them, such as marches through villages with a high Gypsy population organized by the farright Hungarian Guard. The government's populist measures proved incapable of preventing the far right from becoming stronger. The Jobbik (right wing) Party (with close connections to the Hungarian Guard movement) won seats in Parliament in 2010.

\section{How the poor have responded to the situation}

When things happen gradually the boundaries of the impossible and inconceivable are gradually stretched. Today's ghettos of poverty would have been unimaginable even less than twenty years ago. Granted, the beginning, 
the loss of jobs, hit with the suddenness of a blow to the solar plexus, but that was followed by gradual deterioration. A person can get used to just about anything. It would be easy to explain the "ease" of adjustment to the changes using the concept of habitus as used by P. Bourdieu. But there is more than one way of interpreting habitus. We also need to consider differences in the life situations of successive generations, marked by very different historical experiences that have become their "habitus".

People who were thirty years old or more at the time of the regime change had presumably evolved a habitus shaped by hard but predictably regular work and security, albeit of a low level. The new conditions were completely different than the ones which shaped that habitus. So it is not really surprising that people who never had the chance to reflect on or evaluate their own behavior and habits - people with a low level of education whose tenuous hold on the labor market was broken - drifted off uncontrollably into situations they were unable to handle, or thought out new survival strategies which offered only momentary respite (such as borrowing money from loan sharks). People in better situations, particularly if they were able to hold on to (comparatively) secure jobs, may have continued their lives without needing to adjust their former habitus to new conditions. In other cases people with more cultural and other capital were able to form a "reflexive" relationship to their own habitus and change their whole course of life without too much difficulty. The fate of people born and socialized into the new regime depends increasingly on their family circumstances. If they are fortunate, they may choose any course in life and maintain better control over their own destinies than previous generations. On the other end of the social scale, people often become heirs to a new type of deep poverty. For some of the young people the world has become much more open, while for others it is far more closed.

Possible responses to totally new situations irresolvable due to ingrained habitus are the collapse of the family, turning over of the children over to state care, crime, or the complete crumbling of self and vegetation until physical death. Given the ethnic coloration of the veneer that coats poverty, a growing portion of society (possibly the majority) views this as a "Gypsy question". Granted, in the most disadvantaged micro-regions (for which we have 2009 data) 70 percent of the Gypsies and "only" 30 percent of the non-Gypsies are poor. However, given that the Gypsies make up a minority of the population, fully half of the poor even in these micro-regions are not Roma at all.

In principle local efforts may sometimes be helpful even without central dispositions. In some cases a devoted mayor and other dedicated professionals in a settlement with a measure of grant money can try to improve the situation and bring change to local residents including poor and Gypsy residents 
(this can occur through local implementation of the National Strategy against Child Poverty adopted by Parliament in 2007, which got underway in one micro-region and later spread to another dozen of them, using local resources and the European Social Fund). For the moment this is the exception rather than the rule. Individuals who manage to beat the odds are also exceptions. If someone in a remote village where there are no jobs has a family it is well nigh impossible to leave them behind and go off to seek one's fortune. The family would starve. Moving the whole family is out of the question because there is no local market for selling the house and it is impossible to find affordable housing in a town.

It is hard to tell how long the poor will tolerate and be resigned to this deterioration of their lives into hopelessness. It will depend on how bad things get and on the tolerance of their surroundings. Momentarily dormant conflicts could easily trigger open conflicts, even individual or collective uprisings. However, any major escalation in resistance is bound to be thwarted by the isolation of the villages where the poor and the Gypsies live, and by their lack of organization and tools. Yet, unless contemporary problems such as racism, segregation, ghettoization and overall intolerance are remedied, social sustainability and social cohesion will be seriously threatened on an ongoing basis. If civil society were able to raise its feelings of solidarity, concerns could be alleviated. However, even then, the state - despite its very limited scope for maneuvering - should find the resources to begin to mitigate these problems in a tangible way. Whether it will recognize and accept this responsibility remains a key question.

\section{REFERENCES}

Castel, Robert, 1995. Les métamorphoses de la question sociale. Une chronique du salariat. (From manual workers to wage laborers: Transformation of the social question) Paris: Fayard.

Erdős, Zsuzsanna (2010), Gyermekszegénységet, családokat érintő jogszabály változások 2005-2009. (Amendments to child-poverty and family-related legislation, 2005-2009), Gyerekesélyek Magyarországon. (Children's chances in Hungary) 2009 annual report by the Evaluation Committee for the "Making things better for our children" National Strategy, 133-162

Ferge, Zsuzsa (2006), Struktúra és szegénység. (Structure and poverty) In: Kovách, Imre, Ed. Társadalmi metszetek (Social Segments). Budapest, Napvilág Kiadó, 479-500.

Ferge, Zs. et al. (1996), Societies in transition. International report on the Social Consequences of the Transition, a survey carried out as part of the SOCO project 
initiated and coordinated by the Institute for Human Studies, Vienna. Cross-national report on five countries, prepared by Zsuzsa Ferge, Endre Sik, Péter Róbert, Fruzsina Albert. http://www.fergezsuzsa.hu/docs/social costs

Ferge, Zsuzsa (2009) Verseny és emberi kapcsolatok (Competition and human relation), in: Somlai, Péter (Ed.): Látás-viszonyok- Tanulmányok Angelusz Róbert 70. születésnapjára (Conditions of visibility- Studies marking Róbert Angelusz's 70th birthday) Budapest: Pallas, 2009. 369-380

Elizabeth Gaskell (1995), My Lady Ludlow. Chicago, Academy Chicago Publisher

Kertesi, Gábor - Gábor Kézdi (2009), Általános iskolai szegregáció Magyarországon az ezredforduló után (Segregation in primary schools in Hungary in the 21st century) Munkaeröpiaci Tükör, Budapest, Hungarian Academy of Sciences Institute of Economics

Kolosi, Tamás -István György Tóth, (2008), Újratervezés: Életutak és alkalmazkodás a rendszerváltás évtizedeiben (Planning anew: Careers and adjustments in the decades following regime change) Research report on the "Study of household evolvement" (HÉV). Budapest, TÁRKI

The Marmot Review (2010), Fair society, healthy lives. Chair: M. Marmot, Strategic review of health inequalities in England post-2010.

Stiglitz, Joseph E. - A. Sen - J.-P. Fitoussi (2009) Committee report on measurements of economic performance and social development www.stiglitz-sen-fitoussi.fr

Szalai, Júlia (2007), Nincs két ország...? Társadalmi küzdelmek az állami (túl)elosztásért a rendszerváltás utáni Magyarországon (Not two countries...? Social struggles for state (over)distribution in Hungary after the regime change), Budapest, Osiris

Szalai, Júlia (2010) A szabadságtalanság bővülő körei. Az iskolai szegregáció társadalmi „értelméröl” (Expanding circles of non-freedom. The social "rationale" to school segregation) Esély, 21/3. 1-22.

Wilkinson, Richard (2005,) The impact of inequality, New York, The New Press

Wilkinson, Richard (2006), The impact of inequality, Social Research: An International Quarterly 73/2, 711-732. 